\title{
Healing the body between medical practice and Christian moral theology
}

\author{
Fr. Prof. PhD. Leontin POPESCU \\ Faculty of History, Philosophy and Theology \\ "Dunărea de Jos" University of Galați, \\ ROMANIA \\ E-mail: prleonpopescu@yahoo.it
}

\begin{abstract}
The medical world has nowadays become an interesting place of interdisciplinarity, a place where natural, humanist, religious sciences, with their corresponding personalities, come together; they are dedicated to helping the ill / the suffering. The greatest challenge, from this point of view, is precisely the capability of integrating various components so as to provide the patient with the best assistance. However, contemporariness shows us that the development of medical means in a sole naturalist direction has led to objectifying disease which becomes itself a reality, independent, looked upon from an exclusively biological perspective, without the spiritual and moral connections of the person experiencing illness and suffering. This resulted in depriving the ill person of his disease, many physicians treating not the person who is ill, but the specific illness or organ.
\end{abstract}

Keywords: physician, patient, ill person, moral, suffering, pain, person.

\section{INTRODUCTION}

There has always been talk on suffering and there will be until the end of time. It is our historical condition, it encompasses us, it suffocates us sometimes, it causes us anxiety, frustration and rebellion. We are born in suffering and we experience it constantly during our lives. Death itself is often regarded as suffering. The topic of suffering and philosophical reflection on suffering has always given rise to some of the greatest questions of human everyday existence, spread throughout each historical epoch: why? Why is suffering necessary? Which are the reasons behind its existence? What is the point of suffering when faced with the fundamental and central belief of humanity's religious conscience, that is what is its relation to the existence of God? Aren't these incompatible concepts, living in suffering and the existence of God considered Good and Omnipotent at the same time? And, on an even more serious note, how can one reconcile the suffering of an innocent person and God's kindness and omnipotence, as He is called Father [1]? Here are so many questions that man has been confronted with during his earthly existence and on which he has spent very much time, thinking and material things, trying to find answers. Various successful or unsuccessful attempts at answering stand testimony in the meditations in the History of Religions, philosophy, literature and different human expressive art along the centuries. Throughout time, many religious and philosophical systems have tried to clear up the issue of suffering in a satisfactory way. Many have tried to offer a way out of suffering, redemption by avoiding it. The Buddhist way is a case in point. Noticing that all existence is suffering [2], that living actually means suffering, that they overlap, Buddhist reached the conclusion that fleeing [3] is the best solution, that freeing oneself from suffering is freeing oneself from existence. Taking refuge in the 
nothingness, in the non-existence, constitutes the only variant for Buddhist thinking in particular and for extremist Oriental thinking in general. To the contemporary man, suffering can have no spiritual explanation. It seems more of natural degrading to him, one which does not require a spiritual motivation or explanation; that is why the solution is also natural. Man finds no point in it, he considers it absurd and spends his entire life not trying to understand it but struggling to avoid it [4].

On the contrary, Christianity gives great importance to courage, to commitment, and redemption without losing one's identity. Christianity itself is the religion of courage, because true courage implies hope. Courage does not mean giving up when you feel that you cannot win, but fighting against all odds that would signal defeat. Suffering is not a phenomenon, a mere chance happening or a reality which is external or which exists outside man, but an event, or better said, an autobiographical experience that is deeply rooted in human experience [5]. Disease, suffering, and especially incurable disease touch upon the intimate, profound level of human conscience and the individual becomes fragile, sensitive, unstable [6]. Disease, suffering are experienced as a danger: the threat to the individual's own physical, psychological and social identity. And what accompanies it, especially in a paralyzing manner, is fear; the fear that everything is lost, that it cannot be controlled by means of medicine, which leads to the greatest dread: the fear of death [7].

\section{Medicine and healing the body}

There are opinions, which at first sight seem incompatible, according to which disease can only be approached unilaterally, medically or theologically. To establish a dialogue between science and faith regarding suffering and its causes, finding common ground is to be preferred, so that the two domains become complimentary. Thus judging things, we will be able to understand how scientific knowledge stimulate intelligence, at the same time allowing for the development of some more profound dimensions of faith, with the double conviction according to which scientific knowledge provides a better understanding of the founding texts of faith and, as a consequence, it creates a free space where science may develop for the welfare of mankind.

From the perspective of laic medicine, the significance thresholds of the pathological, of passing from the normal to the abnormal and to the morbid are not clear, either in the case of somatic suffering, or, even less so, in the case of mental suffering, where the distinction between normal and pathological require a high degree of fluctuation.

In 1958, the World Health Organization tried to define health as "a state of perfect physical, psychological and social welfare, not consisting only in the absence of illness and disabilities" [8]. This coining of terms, although displaying the advantage of influencing mentalities and implementing new ways of approaching health practices, tends to suggest that one cannot be healthy without that "perfect welfare." Furthermore, the definition could be completed by the moral dimension of man's health and this is because many diseases derive from a person's moral choices: drugs, alcohol, AIDS, violence [9]. Having this perspective on things, it would mean that health programs should be conceived so that each individual be brought to a state of physical, mental and social welfare, according to some standards, sometimes "foreign" to the way in which he lives his life, and, maybe against his own will. So as to experience this integral state of wellbeing, the man must interact with the world, with all that surrounds his entire being: body and soul $[\mathbf{1 0}]$. The human body cannot only be reduced to its significance as a determined network of biological rules. The human body does not represent a vessel, but it is an organ 
of the spirit. It is body, that is a given in space, matter and time, that science studies with precision and competence. Yet, the body does not represent anything beyond its unity principle.

The human body is the being considered in its material state, whereas the soul is the being considered in its spirituality. It thus results that the human body is the carrier of a life project. It is the carrier of a life wish, an effort towards autonomy and participation. Wish is defined as the inner inclination of a person to do or have something [11]. Autonomy represents the individual's capability of conceiving and undertaking a series of actions capable of giving meaning to his life [12]. By participating we understand "take part in."

Consequently, there are four dimensions to health that cross their paths and coexist: the organic, the psychological and mental, the ecological-social and the moral dimension [13].

Disease does not represent only a biological problem, but also an existential one. It does not only mean suffering, pain and isolation, but also a challenge for faith. Man can see another man as a simple "body," but he will find it almost impossible to perceive himself only as a "body." Any conscious experience of one's own structure is always a complete event, body and soul, and not only an experience of the body. This holds valid the other way around as well, for the moral experience is not only an internal, spiritual one, but a complete experience that also involves the psychical dimension of the body. Apparently "natural" inclinations, needs and feelings are never experienced as being purely biological, but they become a part of the moral conscience [14]. The origin of an illness must always be attributed to complex circumstance: physical, psychological, social and moral components.

From a theological point of view, health corresponds to the normal state of human nature, that of the edenic condition and that is why it can be considered as being inherently good. Yet, for a man, the health of the body cannot be an asset acquired forever. Moreover, in this world, it never exists in its absolute form forever, it is nothing but partial and temporary balance, and we might even say that it corresponds to a state of less illness.

The very concept of ideal health escapes our human mentality, as it cannot refer to any experience possible so far. Health, in our present condition, is always related to some sort of balance.

The Holy Fathers assimilate man's health to man's state of perfection to which he is fated to by his own nature. Saint Basil the Great, answering Question 55 of the Great Rules [15] says that medicine is an art that comes from God to heal the body as training for the wisdom of the soul. And he draws a very beautiful parallel between healing the body by the art of medicine and cleansing the soul of sins. If, for healing the body - he says - we undergo surgery, cauterization and we take bitter medicine, the same way, and for healing the soul we must bear the lash of reprimand words and the bitter cure of cannons. What the Saint wants to emphasize, according to the biblical example of the New Testament where the Savior first heals the soul of sins and then heals the body of illness, is the fact that there is close connection between the bodily and the spiritual illness. Medicine is an art in the Holy Father's opinion, but, as any worldly art, is limited and that is why we need good collaboration between the art of healing the body and the art of souls, which is confession. Healing the body and the soul - rule 55 also says - must be accepted with gratitude to God for His caring concern that sometimes manifests itself in 
unseen ways, and some other times by material means so that we might acknowledge His grace sooner.

Another issue brought forth by rule 55 [16] is that of the right use of this art called medicine. Saint Basil the Great says: "Therefore, because some people do not make honest use of the medical art, we ought not to shy away from any good that it could bring... It is not right, because of wrong usage of it, to deny God's gift."

Here we may approach, from the point of view of Christian Morals, the relation established between physician and patient.

First of all, we must state that, many times, the relation with the ill is a minimal one, because either of the suffering that renders him incapable of communicating, or of the physician [17]. Yet, we must mind the fact that the ill is a suffering, vulnerable person who needs help. Sometimes, the ill person is incapable of being aware of what is happening to him; he doesn't always comprehend observance of medical prescriptions; he feels that the evolution of the disease is not his; he wants a competent, attentive, merciful, serene, available and patient physician. Above all these, nowadays, any patient is aware of somewhat general deterioration of the quality of medical assistance. This must also happen because of the fact that a physician nowadays is mostly interested in the scientific, technological and even bureaucratic aspect of the medical act, without paying any attention to the individual problems of the ill person. The ill person, who has become the beneficiary, the user of a public service, often comes across simple service providers. We must not forget that, sometimes, the patient is asking for the impossible. And this is because suffering and death are incomprehensible to the human mind and he cannot clearly set limits between the possible and the impossible. That is why it is compulsory for the physician to take upon himself the art of communicating with the ill person.

From a medical point of view, developing a relation between doctor and patient must be built in stages. The doctor-patient meeting is one that occurs between two different personalities, with two different stands. The spiritual state of each of them primarily contributes to solidifying the relation. This is where an adjusting state should come into play, the two psychologically unlocking personal tendencies, feelings, convictions, and prejudice [18]. Once he has established a connection to the doctor, by revealing symptoms verbally and non-verbally, the patient I waiting for a competentprofessional answer [19] that would reduce or even eliminate those symptoms. The patient may claim information about his illness but this may often lead to misunderstanding and difficulty in the process of treating and curing disease. The patient has rights and duties which, if observed, lead him to gaining health. Many sick people suffer because nobody listens to them. The wish to be cured with sick people and the need for prevention should rank high [20] in the doctor's mind. These are implicitly followed by the duty that makes him aware of his mission as a healer of the sick. Next is the obligation, explicit in medical rules of social conduct, and so on and so forth, which keep the doctor's will and reason within the limits of morality and human dignity, both in his case, and in his patient's case. Everything that the doctor can do to keep patients healthy, cure them and support their lives must be done with conscience, professionalism, commitment, consideration and love. And, from this point of view, according to the classical definition, the doctor is that vir bonus dicendi peritus and his essential virtue is philanthropy [21]. Listening, interviewing, conversing, identifying the patient's illness and personality, prescribing treatment, giving advice and warnings are some of ways in which the doctor works over the patient, to which he has to add those of a Christian-religious nature. The physician thus manifests a 
paternal function towards the patient, similar to maternal or paternal relation [22]. By this - maternal or paternal - model, many researchers understand [23] that the physician must not only be interested in the physical healing of the patient, but also in his moral, psychological and spiritual state [24]. This physician-patient relation model is known to the world of bioethics as the model of "medical friendship" [25]. This "friendship," also translated by an alliance [26], a therapeutical closeness, represents the state in which the physician is capable of compassion or mercy. Here, the classical model of the Church is the model of the Good Samaritan (Lc. 10, 29-37), whose mercy is translated by AGAPE [27], an almost religious dedication by manifesting feelings of affinity, goodwill, and human nature on the part of the physician. On the other hand, on the sick person's part, there should be manifestation of trust, as an answer to the physician's therapeutic attitude [28]. The less paternal the medical practice is, the more the professional conflict increases. This, together with the utilitarian aspect, lead to an ever more "expert" medicine, more and more specialized, but less and less responsible of the patient as a whole [29]. The more nurses and doctors are informed both in the field of science and in that of Christian religion [30], the more their trust in the patient's chances to be cured increases, by methods and means applied, and, at the same time, the patient gains confidence in the competence of the people who take care of him. According to the doctor's prestige, the patient approaches him with certain confidence or suspicion. To be a physician also means two apparently opposed aspects: your welfare (as a physician) and other people's welfare (those you are trying to heal); the proportion between the two is regulated by the norms and rules of medical practice (norms and laws) [31].

Thus, the patient may open his heart and show the doctor all the manifestations of disease, but also the causes of its appearance, which would lead to a close connection between the two by making the patient observe the physician's indications, by making the doctor trust the patient to collaborate with his treatment, and this would actually mean a good relation that would lead to quick healing.

It is the doctor who possesses information on disease occurrence, on its manifestations and on specific treatments for each disease in turn [32]; not only does he have this information, but he also applies specific ways of treating disease, all these being accomplished in the direct relation with the patient who must collaborate during the three stages towards healing: to show all disease manifestations, to listen and become aware of the diagnosis undergoing treatment, and, thirdly, to take part in the healing process by carrying out the doctor's prescriptions.

This doctor-patient or confessor-repentant relation is one of existential communication. To the patient, the doctor is the worthy instrument, endowed with healing powers by God with a view to serving his fellow-men in healing, and the sick person is in its turn, to the doctor, worthy of being healed, having rights and autonomy [33] without discrimination or prior labelling. Hence, so as to better relate to everything that surrounds him, the patient aims at the healing that the doctor may provide, and, in his turn, the doctor leans over the sick person, resorting to all the elements he possesses in order to help the ones in need. We can, therefore, see that there is an interdependence relation between the doctor and the patient: the doctor has no purpose without the ill, and the ill cannot cure them. The doctor-patient relation implies a time to be manifested, a place, and different states of the doctor and of the sick person, it undergoes connected consecutive stages, it follows various relation patterns [34] and it is extended by having Doctor Christ intervene in it. 


\section{Different physician-patient relation patterns}

A first pattern [35] is the one represented by the so-called active-passive relation: one of the two has the power to act, whereas the other ends up by accepting the former's will and actions, in our case usually the physician.

A second pattern is defined as guidance and collaboration: the two, physician and patient together, get into action, but in a diverse way: one has all the power to act and takes into consideration the other's wishes and the latter tries to impose his point of view. A third pattern is that of reciprocal participation: both the physician and the patient have the same persuasive skills, matching various notes characterizing the personality of each of them, of course.

These three human interaction patterns are not mutually exclusive in the medical act, as each of them satisfies different particular requirements, brought about by particular situations. What we must keep in mind is that all medical operators must obey the moral principle of respect and identifying the patient's human values. This principle must make any medical operator (stretcher bearer, nurse, and physician) see the patient as a person, not an object or a client. The status of being a person is not achieved at the same time with gradual physical or cultural development, as one cannot lose this status even if personal functions are not exercised. Consequently, a person means the zygote, the embryo, the human foetus, the new-born, the child, just as persons are the dying, the old, the disabled, and the comatose. That is why human dignity does not depend on psycho-biological health, or on good DNA functioning, but on the sacred dimension of life invested in every man by God [36].

Faced with all these categories of impossible, unwanted, difficult patients, the first thing that the doctor should not do is label them. Labelling a patient means establishing a barrier in communicating with the patient either about therapeutic aspects, or about treating the patient with respect and observing his rights. One of such patient rights is the of the patient's autonomy [37], according to which the sock person, just as any individual, has the right to freedom and self-determination, the right to make choices, the right to be informed on diagnosis, therapy, risks, benefits, advantages and disadvantages of certain therapies. According to the autonomy principle, the physician cannot be the referee regarding the sick person's health [38]. From this point of view, professional competence must serve the integral well-being of the patient, only as a result of the patient giving implicit or explicit authorization to such a course of action. In other words, the patient must be aware and co-responsible as to the interventions he will undergo. The importance of consensus comes from the reason that he is the main expression of an individual's freedom and his right to manage his own healing [39]. In medical acts, consensus is implicit [40] when the patient undergoes prescribed therapies: the patient is certain that the physician is interested and means well, and the physician knows that the patient he is addressing has the utmost confidence in his moral and professional competence. Explicit consensus is, however, needed with medical procedures that present risk for psychophysical integrity or that comes in contradiction with the patient's moral or religious beliefs. A typical case in point is sterilization after repeated $\mathrm{C}$-sections, which, in some cases, is operated without letting the patient know about it [41]. On the other hand, the physician may refuse to perform an intervention or therapy on the patient's express demand. A delicate situation, which has become ever more frequent in Romania, is refusal of medical consensus on religious grounds [42]. For instance, blood transfusions, with 
followers of the Adventist cult and Jehovah's Witnesses, who regard blood transfusions as a breach of the divine law. In this case, the physician will not resort to force and physical or psychological violence, but will approach competent authorities, either to help the patient, or to avoid being accused of a crime by not performing a certain medical act. Under such circumstances, called, in the medical environment, therapeutic obstinacy [43], discerning plays a very important role both for the patient and for the physician. Yet, even here, only the patient can have an integral vision of values that are at play in his case. The physician is under the obligation to inform the patient on his real situation: diagnosis, therapy, prognosis, while preserving professional secrecy - privacy [44]. Although the roles are distinct and diverse, we must say that, in the physician's and the patient's case, both share the status of a human being who experiences suffering as an existential reality, certainly not as something foreign, and, if we think of the physician, he also gets sick, he may experience disease with members of his own family, and, in doing so, he touches upon his own suffering as well as other people's [45].

The physician must not turn into a preacher or a missionary. But the spiritual advice remains a high ideal of his profession, one that he ought to attain as well as possible, with no constraint, with finesse and respecting the patient's beliefs, without taking advantage of his weakness, insecurity and confusion [46]. Consequently, the Christian physician will treat the patient, from the very first moment, with politeness, with human warmth, not forgetting that the true master is the patient himself, as, without him, the physician would not exist. The Christian physician, who is aware that, before him, there is God's face in every patient, will not address the patient informally, will not patronize him as an all-knowing creature, will not yell or scream at his patient; he will not give him pseudo-scientific and technical explanations related to illness evolution. The Christian physician is under the moral obligation to satisfy the need for self-esteem, for security and respect in the patient; the Christian morale obliges him to respect the patient's human values, dignity, ideas, feelings, and religious beliefs. That is why the most valuable quality of a Christian physician is humility [47]. The Christian physician is the person who lives a moral life worthy of his profession and who meets the requirements of Christian Morale in concrete situations of his profession. According to morale, the Christian physician will refrain from any action that would contravene to the principles of the Gospel regarding man, life and serving one's fellow-men.

The physician must be aware that he is an instrument by which God does His work and a collaborator, with whose help God works to eradicate evil from the world. The gift of healing and medical knowledge comes from God, and the physician has the responsibility to use this gift not against his fellow-men and the world, but to support the dignified existence of the person created and to fulfil the meaning of the individual's existence.

A first problem to arise within medical practice, yet being only the reflection of some cultural paradigm of modern Western society, is the tendency to industrialize the medical act. Thus, the imperative of financial profitability lays focus on those elements that allow the patient to be included in a broader class, missing out on those aspects that are specific only to him.

The hospital tends to become a plant, and the employees are constrained to work constantly, paying too little attention, in this process, to the fact that the "material" they are working on in this industry is a live, sensitive and sensible one, not an inert one as with the rest of industries. 
A second problem that we could notice in real life is the one that emphasizes the fact that, no matter if they practice healing or preventing medicine, the purpose is to regain bodily health, mainly ignoring his spiritual issues (an exception to this being illness related to psychiatry).

Assuming that this one-dimensional approach to man's health relies on several factors: on the one hand, one of the Cartesian paradigms lying at the foundation of modern sciences states that man is a live mechanism. Thus, the body is seen as a self-sustaining reality, with an autonomous existence when compared with the soul. Disease would, consequently, be a flaw of this mechanism, medicine being the science that deals with its repairing. The moment the mechanism is made to function again as usually, automatically, the spirit may have the machine to drive as it pleases. This concept displays the clear dichotomy of the individual, which would only be a combination, without any inner interaction, of the body and the spirit of man. Curing the man is not the sum of curing his organs. Curing him at any cost is not the correct indicator to assess the value of the medical act. It is, however, an indicator of the efficiency of the medical system as a whole, taking into consideration the fact that this system includes the patient as well, as a party contributing to his own interest to be cured [48].

On the other hand, another root of this prejudice by which man is considered healthy if his body is not suffering is a result of implicitly materialist mentality, which considers as authentically extant only that which could be experienced via senses (may those be enhanced with the use of apparatus, amplifying their powers). The notions of soul and body render possible the good functioning of the human being. But man represents something more than this, he is a person. The way in which the human being must be looked upon and treated from the Christian perspective relies on the fact that man was created resembling God's face and appearance (Fac. 1, 27). Therefore, each man wears this face, unalienable in its own conscience, in the depth of his being. This means that there is more to man than meets the eye [49]. At this point, we must say [50] that the Church has always paid attention, even if there have often been voices, especially with regard to Orthodoxy, claiming that the Church is conservative and not adapted to the present day. We mustn't go too far in saying that the Church has always talked about man as a person in dialogue with God and his fellow-men. The term person in Orthodoxy has such great value that Orthodox Theology uses it to explain both the Bodily Existence God's Son [51], and His redemption acts because man is that being that orients himself towards God [52] and bears God's face within himself. From this point of view, the Christian Morale states its prosopocentric nature by which Bioethics may be better oriented in applying moral principles.

\section{Mas as person}

When we talk about man as person [53], we refer either to its irreducible identity and the inner dimension that constitute him, or to his relating to other people, relations that can only be due to his quality as a person. To be a person implies ontological order: man either is or is not a person. The status of being a person is not achieved at the same time as gradual physical or cultural development, as it cannot be lost even if personal functions are not exercised [54]. Consequently, a person means the zygote, the embryo, the human fetus, the new-born, the child, just as persons are the dying, the old, the disabled, the comatose. Manifesting functions specific to the person or not manifesting them does not alter the ontological status of person [55]. 
From the Christian perspective, this personal identity, which also represents tension towards another, is essentially founded on the Trinity of divine Persons. Christian teaching speaks of a single God multiplied by three Persons. A single divine nature and three divine Persons: the Father, the Son, and the Holy Spirit. Nature is common to the Three, but each of the three divine Persons possesses it completely. To Christianity, God reveals Himself not as nature, but as Person. To a Christian, God's nature is inaccessible, foreign, and the Person essentially reveals Himself in the Embodiment of God's Son. By this Embodiment and by all redemption acts performed by Christ, man achieves the climax of personalization that is of dialogue and communion with God, according to the supreme trinity model [56].

The same thing happens to man. He reveals himself as person, but his nature is common to all men, and what makes him unique in the universe is exactly the nonrecurring person. People are so different from one another that we cannot find two similar people in the entire human history. What is it that makes man unique and non-recurring? The Holy Fathers and Christian Tradition understood this unique nature of man by the reality of the person, a concept previously unknown to Christianity [57].

When we say that a man is a person, we say that he is not just a fragment of matter [58], an individual element of nature, alike other individual elements of nature: an atom, a wheat ear, a fly, an elephant. Man is indeed an animal and an individual, but unlike no other. Man is an individual that guides himself by intelligence and will; he exists not only physically, there is a richer, higher existence embedded in him, by knowledge and love. In philosophical terms, this means that, in human flesh and bones, there is soul which is worth more than the entire universe. The human being, no matter how independent he might be from the smallest accidents of matter, exists by the soul's own existence, which prevails over time and death. At the root of every person there is soul [59]. Man is, on the one side, a being apart from physical nature, and, on the other, a unitary and composed being.

The fact that, according to the Holy Scripture, man was created apart from the other creatures shows the unitary, but dichotomy-like or bifurcated, as father D. Stăniloae would say, character of man.

By the fact that man is created not only of nature, dust, but also of God's lifeinstilling breath, the soul, it is clearly shown that he holds special position not only in relation to nature from which his body was taken, but also in relation to God. Father Stăniloae provides us with an example here, involving flour and dough, saying that, just as the dough raises all the flour, the same way man is made up of a part of nature in which soul; life was instilled, so that it could raise all the nature [60].

The approach of the Christian Morale is always connected to the way we value the person. Without a correct concept of the human being, we cannot decipher the values of Bioethics and its purpose. And the first golden rule in the case of Christian Morale is the one stated in the Gospel: "All that you would like other people to do to you, do the same to them" (Matthew 7, 21). Man is called upon to put himself in somebody else's shoes and to act towards him as he would like another to act towards himself. In other words, the rule addresses the human being and it is applied by means of understanding and solidarity with one's fellow-men [61].

\section{Conclusion}


Outside Christian understanding, medicine generally misses its target [62]. Without its orientation towards the Kingdom of God, it risks to become a deformed practice, distorted by politics and economic power, a reality in itself and to itself [63], focusing more on the physiological side of man, without taking into account the dichotomy and mysticism of the human being's constitution. Nowadays, more than in the past, we can at least talk about a "humanizing" project [64] of medicine, if not about a conversion to Christian morale [65]. Humanizing the medical act is the preamble to making the Gospel part of the medical act [66]. What gives the medical act the ability to make sense, from a moral point of view, is exactly acknowledging the principle of authority that must not be mistaken for the only medical competence. According to this principle [67], authority lies with the patient/his representative and not with the physician, and the open or implied breach of this principle may be an important source of conflicts. This principle has become the dominant element in making a medical decision. An able and well-informed patient has the moral right to consent to or to refuse the medical intervention [68].

The care for the sick person requires, besides technical-scientific competence, responsibility and moral involvement [69]. The risk of technical-scientific medicine is that of reducing pain and suffering to only "something" physical, to a mechanism-like model [70], without man's moral and religious experience. Functioning in a one-dimensional manner, medicine has looked upon man as a machine. Disease, suffering have been regarded as things to be fixed at a certain moment in man's existence. This manner of considering man has led to huge problems to solve, and resulted in the development of new branches of medicine, especially in the West, such as psychology, psychotherapy and psychoanalysis. On the contrary, today we witness the development of the so-called holistic medicine, which aims at looking upon man as a psycho-somatic organism, whose psychological state influences the body as well, and bodily disease influence, in their turn, the psychological state of man. That is why the field of medicine must be one of interdisciplinary interference: science, religion and culture [71].

Radically separating physical pain and suffering from the rest, medicine may turn into an analgesic form [72]. Moreover, focus is laid on the usefulness of medicine and on emotionalism, everything being assessed by a preferential calculus in terms of quantity: diminishing pain, excluding the fact that suffering is a complete human experience [73]. From this perspective, healing is labelled as "something" that comes from beyond the human being and which is always attributed to professionalism, to the science of the physician who gave the correct diagnosis, who prescribed the adequate treatment. The patient's contribution in this sense consists in listening to and obeying the physician's indications, and not in interacting, in establishing dialogue, in actually experiencing his work [74].

\section{REFERENCES}

[1] Dionigi Tettamanzi, Nuova Bioetica Cristiana, Torino, Piemme, 2001, p. 347.

[2] Aldo Natale Terrin, "Il dolore e la morte nelle religioni", in: Sensul vieţii, al suferintei și al morții (The Meaning of Life, Suffering and Death), The International Symposium in Alba-Iulia, February 29-th - March the 2-nd, 2008, Alba-Iulia, Reîntregirea Publishing House, 2008, p. 63-64.

[3] Maurizio Chiodi, Etica de la Vita, Milano, Edizioni Glossa, 2006, p. 309. 
[4] George Remete, Suferinţa omului şi iubirea lui Dumnezeu (Man's Suffering and God's Love), Bucharest, The Publishing House of the Biblical Institute and of the Romanian Orthodox Church Mission (from now on BIROCM), 2005, p. 11.

[5] Vittorio Made, La sofferenza nella cultura contemporanea, in Gian Maria Comolli e Italo Monticelli, "Manuale di pastorale sanitaria", Torino, Edizioni Camilliane, 1999, p. 117-123, here p. 117.

[6] Michele Aramini, Bioetica per tutti, Torino, Edit. Paoline, 2006, p. 78-79.

[7] Cristina Gavrilovici, Sfârșitul vieții la începutul vietii, (Life's End at the Beginning of Life) in: "Medicii și Biserica" / "Physicians and the Church", vol. VI, Cluj-Napoca, Renașterea Publishing House, 2008, p. 78-96, here, p. 80.

[8] Organizaţia Mondială a Sănătăţii / International Health Organization, Organizaţia mondială $a$ sănătăţii 1958-1962:o bibliografie / International Health Organization 1958-1962: a Bibliography, Geneve, 1964, p. 124.

[9] Elio Sgreccia, Victor Tambone, Manual de Bioetică (Manual of Bioethics), Bucharest, 2001, p. 82.

[10] Stelian Pașca-Tușa, Trupul morții și al salvei-perspectiva biblică și bioetică (The Body of Death and Salvation - the Biblical and Bioethical Perspective), in"Studia Universitatis Babeș-Bolyai. Bioethica", vol. 58, no. 2, Cluj-Napoca, 2013, pp. 67-83, here p. 78.

[11] Academia Română / Romanian Academy, Institutul de lingvistică "Iorgu Iordan" / "Iorgu Iordan" Linguistic Institute, Dictionarul Explicativ al limbii romane / The Explanatory Dictionary of the Romanian Language, 2nd edition, Bucharest, Univers Enciclopedic Publishing House, 1998, p. 316.

[12] Ibidem, p. 74.

[13] E. Sgreccia, V. Tambone, Manual de Bioetică, p. 83.

[14] Marian Machinek, "Despre controversa ce privește dimensiunea normativă a corporalității umane"(On the Controversy Regarding the Normative Dimension of the Human Body), in: Studia Universitatis Babeș-Bolyai. Bioethica, vol. 58, no. 2, Cluj-Napoca, 2013, p. 9-16, here p. 15.

[15] St. Basil the Great, Regulae fusius tractatae, in: J.P. Migne, Patrologiae Graecae (from now on: $P G$.), vol. 31, col. 890-1050, here col. 1043c-1046a

[16] Ibid.

[17] Mircea Gelu Buta, "Întâlnire cu muribunzii" ("Meet the Dying"), in: Medicii și Biserica (Physicians and the Church), vol. VI, Cluj-Napoca, Renașterea Publishing House, 2008, p. 201.

[18] Dr. Ruxandra Răşcanu, Psihologie medicală şi asistenţă socială (Medical Psychology and Social Services), Bucharest, Ştiinţă şi Tehnică Publishing, 1996, p. 147.

[19]Ibid, p. 135.

[20]Dr. Sebastian Nicolau, Bioetică - manual pentru învăţământul universitar şi preuniversitar (Bioethics - a Textbook for the (Pre-)university Educational Systems), Bucharest, Universul Publishing House, 1998, p. 54.

[21] Maurizio Pietro Faggioni, La vita nelle nostre mani, Torino, Edizioni Camilliane, 2009, p. 180.

[22] Ibid, p. 180.

[23] Mark Siegler, The progression of medicine: From physicians paternalism to patient autonomy to bureaucratic parsimony, Arch. Int. Med. 145 (1985) 713-720; Angelo Fiori," Il medico tra ricerca del bene del paziente e rispetto della sua autonomia nel nuovo codice deontologico", in: E. Sgreccia (a cura di), Storia della medicina e storia dell'etica medica verso il terzo millennio, Rubbettino, Soveria Mannelli (Ct) 2000, p.110; Paulo Cattorini; Roberto Mordacci; Massimo Reichlin (acura di), Introduzione allo studio della bioetica, Milano, Europa Scienze Umane Editrice, 1996, p. 122.

[24] Paulo Cattorini, "Alleanza terapeutica", in: Dizionario di Teologia Pastorale Sanitaria, Torino, Edizioni Camilliane, 1997, pp. 30-37, here p. 33.

[25]Edmund D. Pellegrino, David C. Thomasma, For the Patient's good. The Restoration of Beneficente in Health, New York, 1988.

[26] P. Cattorini, voce Alleanza terapeutica, p. 33.

[27] M.P. Faggioni, La vita nelle nostre mani, p. 183.

[28] Gracia Gullien, "Orientamenti e tendenze della Bioetica nell'area linguistic spagnola”, in: Viafora Corrado. (Coord.), Vent'anni di bioetica. Idee protagonisti istituzioni, Padova, Fondazione Lanza, 1990, p. 290.

[29] George Cristian Curcă, “Aspecte conceptuale privind răspunderea deontologică și malpractica medicală” (Conceptual Aspects Regarding Deontological Responsibility and Medical Malpraxis), 
in: Revista Română de Bioetică, (The Romanian Journal of Bioethcis), vol. 8, no. 1, Iași, 2010, p. 57.

[30] Dr. Ruxandra Răşcanu, Psihologie medicală şi asistenţă socială (Medical Psychology and Social Services), Bucharest, Ştiinţă şi tehnică Publishing, 1996, p. 9.

[31] [G. C. Curcă, Aspecte conceptuale ..., p. 54.

[32] Sandro Spinsanti, "Salute, malattia, morte", în Francesco Compagnoni \& com (coord), Nuovo Dizionario di Teologia Morale, Torino, Edit. San Paulo, 1990, pp. 1134-1143, here p.1137.

[33] Leontin Popescu, "Relaţia medic-pacient din punct de vedere al moralei creştine" (The PhysicianPatient Relation from the Point of View of Christian Morale), in: Teologie şi Educaţie la Dunărea de Jos (Theology and Education at Dunarea de Jos), Vol. XI, p. 380-392, Galați, Arhiepiscopiei Dunării de Jos Publishing, 2012, p. 389.

[34] Ibid, p. 387.

[35] Alfredo Nazani, Le dimensioni etiche della relazione umana: limiti, obblighi, valori e responsabilita di fronte all altro, in sanita, în Gian Maria Comolli e Italo Monticeli, Manuale di pastorale sanitaria, Torino, Edizioni Camilliane, 1999, pp. 303-309, here pp. 304-305.

[36] John Breck, "Prunc s-a născut nouă". Etica ortodoxă şi copilul care vine pe lume, (A Child was born to us. Orthodox Ethics and the child that comes into the world), in vol.: Bioetica şi taina persoanei (Bioethics and the Mistery of Person), Bucharest, Bizantină, 2006, pp. 75-91, here p. 86.

[37] M. P. Faggioni, La vita nelle nostre mani, p. 183.

[38] Ibidem.

[39] M. Aramini, Bioetica per tutti, p. 93.

[40] Paulo Girolami, "La deontologia medica, il codice deontologico e l'eutanasia. I motivi di un No", in: Studia Bioethica, vol. 3, nr. 1-2, Roma, Italy, 2010, pp. 31-39, here p. 34.

[41] M. P. Faggioni, La vita nelle nostre mani, p. 184.

[42] Horațiu Crișan, "Abordări teoretice ale deciziilor controversate în etica medicală” (Theoretical Approaches to Controversial Decisions in Medical Ethics), in: Studia Universitatis Babeș-Bolyai. Bioethica, vol. 58, no. 2, Cluj-Napoca, 2013, pp. 29-38, here p. 30.

[43] M. Aramini, Bioetica per tutti, p. 262.

[44] M. P. Faggioni, La vita nelle nostre mani, pp. 188-1889.

[45] P. Girolami, La deontologia medica, il codice deontologico..., p. 34.

[46] J. C. Larchet, Creştinul în faţa bolii, suferinţei şi morţii (The Christian facing Disease, Suffering and Death), translated from French by Marinela Bojin, Bucharest, Sofia, 2004, pp. 96-97.

[47] Pavel Chirilă \& com, Principii de bioetică. O abordare ortodoxă (Principles of Bioethics. An Orthodox Approach), Bucharest, Christiana, 2008, pp. 150-151.

[48] G. C. Curcă, Aspecte conceptuale ..., p. 54.

[49] Mircea G. Bută, Pavel Chirilă, Adina Rebeleanu, Bioetica și identitatea persoanei umane (Bioethics and the Identity of the Human Being), in: Revista Română de Bioetică (The Romanian Journal of Bioethics), vol. 8, no. 3, Iași, 2010, pp. 29-35, here p. 32.

[50] Leontin Popescu, Bioetica și perspectiva creștină (Bioethics and the Christian Perspective), Brăila, Istros, 2009, p. 13.

[51]Dumitru Stăniloae, Teologia Dogmatică Ortodoxă (Orthodox Dogma Theology), vol. III, 2nd edition, Bucharest, BIROCM Publishing House, 2003, p. 113.

[52] Dominique Beaufils \& com, Bioetica şi Taina persoanei. Perspective ortodoxe (Bioethics and the Secret of the Person. Orthodox Perspectives), translated from French by Nicoleta Petuhov, Bucharest, Bizantină, 2005, p. 40-41.

[53] L. Popescu, Bioetica și perspectiva creștină, p. 31.

[54] Ibidem.

[55] Michele Aramini, Manuale di Bioetica per tutti, Edizioni Paoline, Milano, 2006, p. 104-105.

[56] Pr. Ştefan Buchiu, Intrupare şi unitate (Embodiment and Unity), Bucharest, Libra, 1997, pp. 139140.

[57]Pr. Ioan Ică, Dr. Alexandros Kalomiros, diac. Andrei Kuraev, pr. Doru Costache, Sfinţii Părinţi despre originile şi destinul cosmosului şi al omului (The Holy Fathers on the Origins and Destiny of the Universe and of Man), Sibiu, Deisis, 2003. p. 58.

[58] L. Popescu, Bioetica și perspectiva creștină, p. 32.

[59] J. Maritain, I diritti dell'uomo e la legge naturale, Milano 1977, pp. 4-5.

[60][60] D. Stăniloae, Teologia Dogmatică Ortodoxă, (Orthodox Dogma Theology), vol. I, 2-nd edition, Bucharest, BIROCM, Publishing House, 2001, p. 406. 
[61] Georgios Mantzaridis, Globalizare şi Universalitate. Himeră şi Adevăr, (Globalization and Universality. Chimera and Truth), translated from Greek by Rev. prof. dr. Vasile Răducă, Bizantină, Bucharest, 2002, p. 155.

[62] H.Tristram Engelhardt jr., Fundamentele Bioeticii creștine (The Fundamentals of Christian Bioethics), Sibiu, Deisis, 2005, p. 411.

[63] J-C. Larchet, Teologia bolii (Disease Theology), translated from French by pr. prof. Vasile Mihoc, Sibiu, "Oastea Domnului", 1997, p. 9.

[64] E. Sgreccia, V. Tambone, Manual de Bioetică, p. 76: "We talk today about humanizing medicine, but there are different concepts in this term, or, if you will, complementation among them: some understand by it the emphasis of the inter-subjective relation between the patient and the medical personnel faced with technology invasion or making hospitals a mass-phenomenon; others understand by it the introduction of humanist studies, especially psychology in the curricula of Faculties of Medicine; but the most profound significance of this concept, in a more conclusive way as compared to the others, consists in acknowledging the dignity of the person in every human subject..."

[65] M. Chiodi, Etica de la Vita, Milano, p. 307.

[66] Gian Maria Comolli, "Umanizzazione del mondo sanitaria", în: Gian Maria Comolli e Italo Monticeli (coord), Manuale di pastorale sanitaria, Torino, Edizioni Camilliane, 1999, p. 243.

[67] Cf. Horațiu Crișan, "Abordări teoretice ale deciziilor controversate în etica medicală" (Theoretical Approaches to Controversial Decisions in Medical Ethics), in: Studia Universitatis Babeș-Bolyai. Bioethica, vol. 58, no. 2, Cluj-Napoca, 2013, p. 29-38.

[68] Diana Cimpoeșu, Irinel Rotariu, Irina Costache, Antoniu Petriș, "Decizia “de a nu resuscita" (II). Etică şi lege în resuscitarea cardiopulmonară”(The "Do Not Resuscitate" Decision (II). Ethics and Law in Cardiopulmonary Resuscitation), in: Revista Română de Bioetică, vol. 10, no. 2, Iași, 2012, p. 30 .

[69] M. Chiodi, Etica de la Vita, p. 308.

[70] S. Spinsanti, Salute, malattia, morte, p.1135.

[71] Ierotheos Vlahos, Bioetică și Bioteologie (Bioethics and Biotheology), Bucharest, Christiana Publishing, 2013, p. 224.

[72] M. Chiodi, Etica de la Vita, p. 309.

[73] Ibid, p. 310.

[74] S. Spinsanti, Salute, malattia, morte, p.1137. 